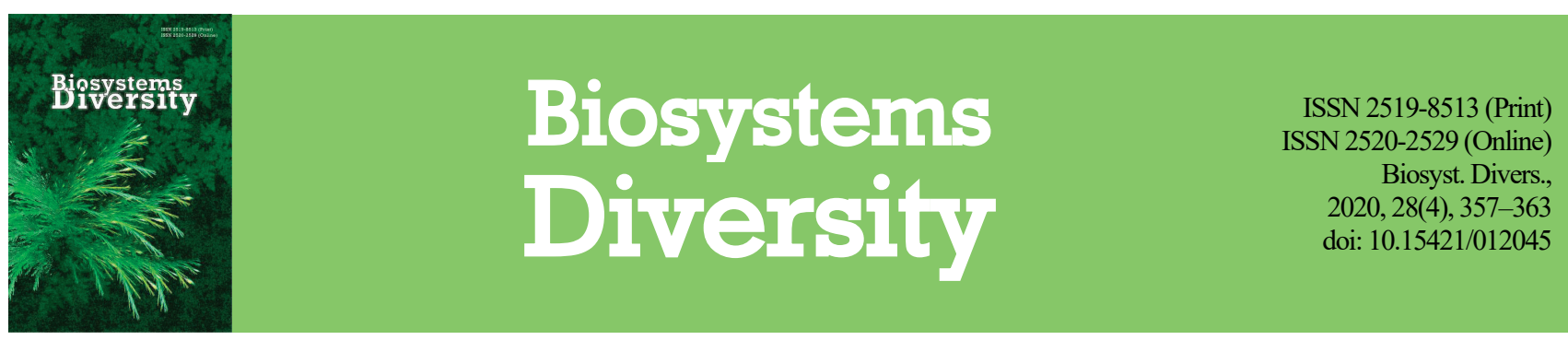

\title{
Patterns of vegetation succession in abandoned fields in semi-arid conditions
}

\author{
L. P. Borovyk \\ Luhansk Nature Reserve of NAS of Ukraine, Stanytsia Luhanska, Ukraine
}

Article info

Received 25.09.2020

Received in revised form 23.10.2020

Accepted 24.10.2020

Luhansk Nature Reserve of NAS of Ukraine

Rubizhna st., 95

Stanytsia Luhanska,

93602, Ukraine.

Tel.: +38-093-564-51-06

E-mail:

larisaborovyk@gmail.com

\section{Borovyk, L. P. (2020). Patterns of vegetation succession in abandoned fields in semi-arid conditions. Biosystems Diversity, 28(4), 357-363. doi:10.15421/012045}

Successions in old fields were studied on the example of the Starobilski steppes within Luhansk Oblast (Ukraine), region located in the basin of the left tributaries of the Siversky Donets, in the southern spurs of the Central Russian Upland. Stationary surveys were conducted in the Striltsivsky Steppe affiliate of the Luhansk Nature Reserve, with 269 ha of old fields ( $26 \%$ of the area) in its territory. Geobotanical releves were performed in 26 plots of abandoned fields, constant monitoring surveys were carried out in 15-27 year-old abandoned fields in the territory of the Reserve and 5-15 year-old abandoned fields in the territory of its buffer zone. In total, the itinerary and detailed surveys were conducted for about 50 plots of abandoned fields. The restoration of the steppe communities was seen only in the plots where grazing and/or mowing took place, which prevented the formation of dense litter and distribution of woody species. The long domination of rhizome grasses (Elytrigia repens) were characteristic in conditions of moderate-level disturbance (in the reserve), transition to the domination of bunchgrasses (Festuca valesiaca) was seen at the age of around 25 years, during the transitional period (20-25 years) communities with unstable structure formed, comprising E. repens, F. valesiaca and forbs (Achillea pannonica and Fragaria viridis). Duration of the stage of segetal and ruderal species in the sites under low effect was 10 years, the communities of unstable structure formed at the age of 5-10 years. In the conditions of stable moderate and high effect of grazing (high disturbance), we observed formation of bunchgrass communities at the age of 15 years. In the unused plots, we saw formation of phytocoenoses of shrubs at different stages of succession, starting from 10 years. The most abundant group of such kind comprised thickets of Ulmus pumila (with E. repens and Poa angustifolia in the herbaceous layer) and Prumus stepposa. The peculiarity of contemporary processes in the abandoned fields related to exacerbation of the vegetation's anthropogenic transformation is distribution of alien tree species from plantations, the most aggressive of which are Ulmus pumila, Fraxinus lanceolata, Acer negun$d o$, Elaeagnus angustifolia. The peculiarity of the succession processes in the region of studies was the domination of species of broad ecological spectrum, characteristic for abandoned fields of northern forest-steppe regions (Bromopsis inermis, Calamagrostis epigeios, Poa angustifolia, Fragaria viridis) and southern steppe regions (Bromus sguarrosus, Anisantha tectorum, Achillea pannonica, Artemisia austriaca), certain communities form dependent on the climatic conditions and type of land use in the period of succession in particular plots.

Keywords: secondary succession; nature reserve; restoration of steppe; successional series; alien species.

\section{Introduction}

One of the key issues in studies of abandoned field in the steppe zone is whether restoration of rare steppe biocenoses is possible in general, and to what extent the rare communities and species are capable of recovering in former arable lands. Abandoned fields are more and more often being considered in the context of preservation of biodiversity, especially regarding steppes, since particularly the steppe biome is one of the centers of genesis of specific flora and unique plant communities (Didukh, 2020).

Secondary grasslands, including the succession stage of abandoned arable fields, are an integral part of the landscape (Denglera et al., 2014). Abandonment of arable fields in the period of transition of the system of land use is a common phenomenon in the world, therefore successions in abandoned fields are studied frequently. The objectives of studies are general patterns in the succession processes (Osbornova et al., 1990; Knapp et al., 2016; Clark et al., 2019), and a number of reviews on this topic have been performed (Cramer \& Hobbs, 2007; Cramer et al., 2008), the most recent was conducted by Clark in 2017 (www.oxfordbibliographies.com).

Restoration of vegetation in abandoned fields starts from initial communities and develops towards the natural vegetation (Suyundukov et al., 2008; Sojnekova \& Chytry, 2015; Olijnyk \& Parpan, 2017). Succession in abandoned fields is considered as spontaneous secondary succession and leads to the formation of semi-natural vegetation (Csecserits \& Rédei, 2001). Species with short life-span are mainly annuals and biennials which produce a great number of diasporas, dominate during initial stages of succession (Osbornova et al., 1990). Diversity of the initial communities was high; conversion to more stable species takes place during the succession (Randall \& Pickett, 1990). Species composition of abandoned fields over time becomes similar to that of natural communities (Ruprecht, 2006). However, the process of restoration of the natural communities is very long, and perhaps the primary structure is unachievable (Reichhardt, 1982). The management of the territories, particularly the removal of biomass has a favourable effect on the structure and composition of plant communities during restoration successions (Ruprecht et al., 2015; Dowhowera et al., 2020). Contemporary attention to the survey of abandoned fields is related to the fact that fallow lands are more and more often considered for restoration and protection of rare species and communities (Sojnekova \& Chytry, 2015; Lysogoret al., 2016). Recently, a large amount of studies have emerged concerning various methods of ecological restoration of natural communities, consisting of using the methods of enhancing the succession due to introduction of seeds (or vegetative parts) of species of late stage for inhibition of the weedy stage development and creation of secondary communities (Vander Putten et al., 2000; Török et al., 2010; Albert et al., 2019).

The general scheme of the succession in abandoned fields of the steppe zone was summed up in the early XX century by K. M. Zaleskiy and includes a series of consequent stages: young abandoned fields (or weedy stage) $\rightarrow$ middle-age (rhizome-grass stage) $\rightarrow$ old (bunchgrassstage) $\rightarrow$ stage of the secondary steppe. Despite the simplicity of the classical scheme, the succession process is complex; it has a significant duration, and is not clearly defined and consistent due to the variety of factors 
influencing its course (Lavrenko, 1940). The objectives of this article were peculiarities of successions in abandoned fields in the Starobilski steppes, contemporary orientations and tendencies of the dynamics, perspectives of steppe restoration in abandoned fields of the Luhansk Nature Reserve.

\section{Materials and methods}

The area of the surveys was located in the north of the steppe zone, in the basin of the left tributaries of the Siversky Donets, in the southern spurs of the Central Russian Upland. According to the geobotanical zoning the area of the surveys belongs to the Siverskodonetsky county of the Seredniodonska steppe sub-province of Pontic steppe province of the Eurasian steppe region. According to various sources, the territory is also called Starobilska plain or Starobilski steppes (Fisunenko \& Zhadan, 1994; Didukh \& Shelyag-Sosonko, 2003; Rudenko, 2007). The area of the survey includes the eastern part of the Starobilski steppes within Luhansk Oblast (Milovsky, Bilovodsky, Starobilsky and Stanytsia-Luhanska districts). The general incline of the area is oriented towards the valley of the Siversky Donets, the largest rivers of the region - the Aidar, Derkul, Krasna, Komyshna rivers. The relief is characterized by the high degree of development of a gully-ravine network, its density accounting for 0.5 $1.2 \mathrm{~km} / \mathrm{km}^{2}$. Zonal soils are common chernozems, average-deep, lowhumus ones on loess-type loams. The slopes have carbonate, send, saline soils, and outcrops of the native rocks, the commonest being cretaceous outcrops. The climate in the region is moderately continental, the average annual air temperature (over 1986-2005) equaled $7.7^{\circ}$, the annual amount of precipitations $-536 \mathrm{~mm}$, the climatic parameters according to the years were characterized by significant instability, typical for steppe zone (Vlasov, 2011). The zonal vegetation of the region is represented by mesophytic variant of forbs-bunchgrass steppes (Lavrenko et al., 1991). According to the ecological conditions and peculiarities of the climate, the region is characterized by a great diversity of biotopes, vegetation, presence of significant amount of rare species and communities, relatively high degree of preservation of natural and semi-natural complexes and is the key area for surveys and nature-protection in the steppe zone (Bilyk, 1973; Barbarych, 1977; Chusova, 2018).

Stationary surveys were conducted in the Striltsivsky Steppe affiliate of the Luhansk Nature Reserve, young abandoned fields were described outside the Nature Reserve. The total area of the abandoned fields in the Striltsivsky Steppe was 269 ha, or $26 \%$ of the area, 9 large sites of abandoned fields the total area of which accounts for 267 ha were adjoined to the Reserve after its expansion in 2004. The area of separate plots varied 10 to 65 ha. Particularly these areas became the object of stationary studies. Another 17 plots were in-detail studied outside the Reserve, their area ranging 0.5 to 30 ha. In general, the itinerary, in-detail and stationary surveys covered around 50 plots of abandoned fields.

All the examined plots were ploughed over for no less than 10 years. Abandoned fields located in the territory of the Reserve were tilled in 1970 and abandoned at different times (around 1990). In the territory of the Reserves' buffer zone, the plots were tilled around the same time and abandoned in 2000 . All plots in general have good conditions for introduction of seeds of steppe species, border with or are located near the slopes of gullies with steppe fragments. The moisture regime in the period of formation of vegetation in the abandoned sites varied, the seasons of 2003-2006 being intensely humid, and the seasons of 2007-2015 being mostly dry and extremely dry. Extremely dry seasons occurred in 2008, 2009, 2010, 2012, 2013, and 2014.

The material for the study comprised geobotanical releves and the data on the vegetation distribution in geobotanical profiles. For comparison we studied etalon steppe communities of the Reserve. Stationary surveys comprised descriptions of fixed plots and profiles. Geobotanical releves and surveys of profiles were performed according to the standard methods (Aleksandrova, 1964; Mirkin \& Naumova, 2012). In the territory of the Reserve, the stationary surveys have been carried out since 2005 , other plots were examined in 2005-2017. In total, in the abandoned areas around 1,000 releves were made: 253 regarding young, 396-middle-age, and 350 - old plots. Number of releves for some plots was $20-30$. For comparison, the used data from the etalon plot was 139 releves for steppe communities with dominance of Stipa zalesskii Wilensky ex P. A. Smim. and S. tirsa Steven. Taxa names are given according to the nomenclaturetaxonomic guide (Mosyakin \& Fedoronchuk, 1992) and Web-site The International Plant Names Index (IPNI) (www.ipni.org).

To develop the schemes of succession, we used observations made directly in the territory of the Reserve and the protected area. Also, we employed the method of substituting spatial scale into temporal (spacefor-time substitution) (Aleksandrova, 1964; Pickett, 1989; Tkachenko, 2009). Direct observations were carried out in abandoned fields with successive age of 15-27 years in the conditions of moderate agricultural impact and successive age of 5-15 years in the conditions of low or no effect. Young abandoned sites were described in plots that for some time (up to 10 years) underwent spontaneous successions over different regimes, but later were tilled. The effect from grazing was also seen in different plots which for several years (1-3) had been intensely used for this purpose.

Type of agricultural use of the abandoned plots was different. For practicability of the analysis, we distinguished scales of moderate, high and no disturbance according to the use. Plots where young abandoned field were used with low intensive, used for grazing for short period, and burned after accumulation of dry remains were identified to the scale of moderate disturbance. Abandoned plots with rhizome-grass were mown, not mown in dry years with low yield, and old abandoned plots (around 20 years of age and older) were used for grazing with average intensity. To the same scale, we classified the abandoned plots in the areas with crops of perennial herbs mowed systematically at initial stages. In the scale of strong effect, a course of successions in the conditions of constant grazing is considered. Plots which were completely unused or experienced short-time disturbance which poorly affected the course of the succession (spontaneous fires or grazing, sometimes) were identified to the scale of absence of the impact (no disturbance). As moderate grazing impact we consider grazing throughout the vegetation season with intensity of 1 cow per 1-2 ha of the area, high impact of grazing -2 and more cattle per 1 ha of the area.

\section{Results}

Change in the role of species according to the age of succession. Arrays of geobotanical releves were grouped according to the change in the structure of dominance (Table 1): 1-2 years - dominance of segetal species, 3-9 years - dominance of ruderal species. In the communities of successive age of 10-20 years, rhizome grasses dominated; due to the duration the stage was divided into two periods (10-15 and 15-20), 2025 years - transitional period of growing of bunchgrasses. The terminal stage of succession is natural steppe phytocenoses, and therefore to assess the degree of restoration, the secondary communities were compared with the steppe ones.

Succession schemes depict the changes in the structure of dominance according to the age and orientations of the development of serial communities. Succession schemes were developed for abandoned fields under different intensity of agricultural use - in the conditions of moderate and high disturbance (or grazing) and no impact.

Scale of moderate disturbance reflects typical course of succession, most favourable for restoration of populations of steppe species (Fig. 1). According to such a scheme, the Reserve's abandoned fields with mowing-grazing regime underwent de-mutation.

According to the data, the abandoned fields of age of 1-2 years had largely diverse communities of segetal species; the scheme shows only the commonest variants. Apart from the species given schemes, initial stage dominants were Convolvulus arvensis, Euphorbia virgata, Falcaria vulgaris, Sinapis arvensis L., Setaria glauca, Xantium albinum (Widder) H. Scholz. In some plots, formations of communities with dominance of Elytrigia repens were seen already during the first year. Over the succession age (3-9 years), there were registered communities with dominance of ruderal species - Artemisia absinthium, Carduns acanthoides, Cirsium setosum, which form mosaic-pattern grass stand. In some years, the formation of communities with Melilotus officinalis (L.) Pall. and M. albus Medik. was observed. The main dominant of rhizome-grass communities (5-20 years) was Elytrigia repens, co-dominant commonly being Poa angustifolia. In the places of perennial plant crops, if they included Bro- 
mopsis inermis (Leyss.) Holub, it took the place of Elytrigia repens. The commonest dominant of bunchgrass communities ( $20-30$ years) was Festuca valesiaca, communities with dominance of species of Stipa L. genus were recorded fragmentally.

\section{Table 1}

Change in the role of species according to the succession years in Starobilski steppes (Luhansk Oblast, Ukraine) compared with the steppe ones (Striltsivsky Steppe affiliate of Luhansk Nature Reserve, Luhansk Oblast, Ukraine) 2005-2017

\begin{tabular}{|c|c|c|c|c|c|c|}
\hline \multirow[b]{2}{*}{ Species } & \multicolumn{5}{|c|}{ Abandoned fields } & \multirow{2}{*}{$\begin{array}{c}\text { Steppe } \\
\text { commu- } \\
\text { nities }\end{array}$} \\
\hline & $1-2 *$ & $3-9$ & $\begin{array}{l}10- \\
15\end{array}$ & $\begin{array}{l}15- \\
20\end{array}$ & $\begin{array}{l}20- \\
25\end{array}$ & \\
\hline Thlaspi arvense L. & $3^{* *}$ & 1 & - & - & - & - \\
\hline Conysa canadensis (L.) Cronq. & 4 & 2 & 1 & 1 & 1 & - \\
\hline Fallopia convolvulus (L.) Á. Löve & 3 & 3 & 1 & 1 & - & - \\
\hline Setaria glauca (L.) P. Beauv. & 4 & 3 & 1 & 1 & - & - \\
\hline Lappula squarrosa Dumort. & 3 & 3 & 1 & 1 & 1 & - \\
\hline Sonchus arvensis L. & 4 & 3 & 1 & 1 & 1 & - \\
\hline Lactuca saligna L. & 3 & 3 & 1 & 1 & 1 & - \\
\hline L. serriola $\mathrm{L}$. & 5 & 4 & 2 & 1 & 1 & - \\
\hline Stachys anпиа (L.) L. & 3 & 3 & 2 & 1 & 1 & - \\
\hline Lactuca tatarica (L.) C. A. Mey. & 4 & 3 & 2 & 2 & 1 & - \\
\hline Artemisia absinthium L. & 3 & 5 & 2 & 2 & 1 & - \\
\hline Consolida regalis S. F. Grey & 4 & 3 & 4 & 2 & 2 & - \\
\hline Taraxacum officinale Wigg. & 4 & 3 & 3 & 3 & 1 & - \\
\hline Melilotus officinalis (L.) Pall. & 2 & 3 & 4 & 1 & 2 & - \\
\hline Daucus carota L. & 3 & 5 & 3 & 4 & 2 & - \\
\hline Picris hieracioides L. & 2 & 3 & 3 & 4 & 3 & - \\
\hline Senecio grandidentatus Ledeb. & 2 & 4 & 3 & 5 & 4 & 1 \\
\hline Carduus acanthoides L. & 3 & 5 & 3 & 4 & 4 & - \\
\hline Agrimonia eupatoria L. & 1 & 3 & 4 & 5 & 5 & 2 \\
\hline Verbascum lychnitis L. & 1 & 3 & 3 & 3 & 4 & 2 \\
\hline Cichorium intybus L. & 1 & 2 & 4 & 3 & 3 & - \\
\hline Securigera varia (L.) Lassen, & 1 & 2 & 3 & 3 & 3 & 5 \\
\hline Cirsium ucranicum Besser & 1 & 2 & 1 & 4 & 4 & 1 \\
\hline Poterium polygamum Waldst. \& Kit. & - & 1 & 2 & 5 & 5 & - \\
\hline Artemisia austriaca Jacq. & 1 & 1 & 3 & 4 & 5 & 5 \\
\hline Medicago romanica Prodan & - & 1 & 3 & 4 & 4 & 5 \\
\hline Potentilla argentea $\mathrm{L}$. & - & 1 & 2 & 5 & 5 & 1 \\
\hline Eryngium campestre L. & - & - & 1 & 4 & 4 & 2 \\
\hline Fragaria viridis Duchesne & - & - & 1 & 4 & 4 & 4 \\
\hline Festuca valesiaca Schleich. ex Gaudin & 1 & 2 & 4 & 5 & 5 & 5 \\
\hline Phlomis pungens Willd. & - & - & 2 & 5 & 5 & 5 \\
\hline $\begin{array}{l}\text { Verbascum marschallianum Ivanina } \\
\& \text { Tzvelev }\end{array}$ & 1 & 1 & 2 & 3 & 5 & 5 \\
\hline Galium octonarium (Klokov) Soó & - & - & 2 & 3 & 4 & 5 \\
\hline Plantago urvillei Opiz & - & - & 2 & 3 & 3 & 5 \\
\hline Scabiosa ochroleuca L. & - & 1 & 2 & 2 & 5 & 5 \\
\hline $\begin{array}{l}\text { Cirsium setosum (Willd.) Besser ex M. } \\
\text { Bieb. }\end{array}$ & 5 & 5 & 4 & 4 & 4 & 1 \\
\hline Euphorbia virgata Waldst. \& Kit. & 4 & 4 & 5 & 4 & 4 & 1 \\
\hline Elytrigia repens (L.) Nevski & 3 & 3 & 3 & 3 & 3 & 1 \\
\hline Achillea pannonica Scheele & 1 & 3 & 4 & 5 & 5 & 5 \\
\hline Convolvulus arvensis L. & 5 & 5 & 5 & 5 & 5 & 3 \\
\hline Poa angustifolia L. & 1 & 4 & 4 & 5 & 5 & 5 \\
\hline Falcaria vulgaris Bemh. & 3 & 2 & 4 & 5 & 5 & 5 \\
\hline $\mathrm{N}^{* * *}$ & 133 & 125 & 70 & 115 & 120 & 139 \\
\hline
\end{tabular}

Notes: $1-2 *$ age of succession, years, $* * 1-5-$ constancy of species - classes: $1-<20 \%, 2->20-40 \%, 3->40-60 \%, 4->60-80 \%, 5->80-100 \%$; $\mathrm{N}^{* * *}-$ amount of releves according to years.

Scale of strong impact (high disturbance) reflects the formation of communities in the conditions of systematic grazing disturbances (Fig. 2). It includes the variant of succession with moderate load and overgrazing. As the initial communities, we considered the ones of early stage formed in the conditions of systematic grazing. In addition for the variant with stable grazing influence, the scheme contains a variant of succession where grazing stopped after the initial communities had formed.

In the condition of intense grazing, the young abandoned plots were recorded to have communities with annual ruderant grass (Bromus sguarrosus and Anisantha tectorum) with inclusion of Artemisia absinthium. In the conditions of overgrazing, in the plots of different age, we observed formation of communities with dominance of Artemisia austriaca, while
Poa bulbosa L., typical for virgin plots with excessive grazing, was completely absent. In the conditions of decrease in the grazing impact, after 12 years, there were recorded communities with dominance of Festuca valesiaca, and after the grazing had stopped, they transformed into communities with dominance of rhizome grasses.

In young abandoned plots (5 years), after grazing had stopped, we saw weed communities returning. According to such a scheme, succession occurred in the buffer zone of the Reserve (Fig. 3). If the grazing lasted for a short period (in this case two seasons), we observed the dominance of return of the species of early stages - Artemisia absinthium and Carduus acanthoides. Scale of absence of impact (no disturbance) reflects the course of succession in the conditions of absence or shortperiod impact (Fig. 4).

In the conditions of absence of impact, we recorded formation of shrub communities, the earliest period of appearance of such coenoses being around 10 years. The commonest communities of such a scale were thickets of alien species Ulmus pumila L. with Elytrigia repens and Poa angustifolia in the herbaceous layer, and in more mesophytic conditions (small gullies and near the forest windbreaks), the thickets were formed by alien species Fraxinus lanceolata Borkh. and Acer negundo L. At the age from 15 years, there was observed formation of shrub communities of aboriginal species Prumus stepposa Kotov, Rhamnus cathartica L., Acer tataricum L.) which form local thickets (in separate plots, in more humid conditions, near forest windbreaks).

\section{Discussion}

In the early stages of succession (1-2) the basis of communitiesis formed by segetal species, in the weedy stage (3-9 years) - ruderants of broad ecological amplitude. During the succession, the participation of some steppe species of broad amplitude regarding the factor of synantropization rapidly increases (10-15 years), such species were abundant on grazing sites, grew in different anthropogenic biotopes and also were distinctive for steppe phytocenoses. There was found a group of species that were common to all the abandoned fields and a group of species common to the abandoned fields and steppe communities.

According to the classical scheme, the period of the weedy stage is usually short, equaling 2-4 years, and the period of the rhizome-grass stage is much longer - up to 13-15 years, but delay of up to 22-24 years is possible (Osychnyuk, 1973).

According to our data, the period of the stages in different plots varies significantly. Some described plots were observed to have the weedy stage delayed for up to 10 years. Transition to the dominance of rhizome grasses occurred quickly or occurred very slowly (depending on the presence of Elytrigia repens in agrocenoses). Transition to the rhizome-grass stage is completed by the 10th year, no plots with dominance of ruderant plants older than this age were observed.

In the Reserve's plots we observed delay during the rhizome-grass stage which lasted for 25 years. Over a long period of rhizome-grass stage, communities with Elytrigia repens, E. intermedia, Bromopsis inermis, Poa angustifolia formed, rarer - Elytrigia trichophora (Link) Nevski, Calamagrostis epigeios (L.) Roth. Shrub thickets formed quickly (at 10year succession age), directly from the weedy stage, or from any stage after removal of agricultural disturbance (local thickets were observed in different plots).

Between the stages, there occurred long transitional periods, when unstable transitional communities formed and various forb coenoses spread. Such periods were recorded in the plots of successive age of 5-10 and 20-25 years. In young abandoned plots, communities of ruderal and meadow-steppe forbs developed. Common communities in the Reserve were the ones with equal participation of rhizomegrasses, bunchgrasses and meadow-steppe forbs (most often with participation of Festuca valesiaca, Elytrigia repens, Fragaria viridis, Achillea pannonica). The transitional periods were distinctive for formation of fragments with dominance of species of several subsequent stages in abandoned plots of the same age. The commonest forb communities were those with Achillea pannonica and Fragaria viridis. Thus, the course of succession was different for the sites, in general slow with long transitional periods. 


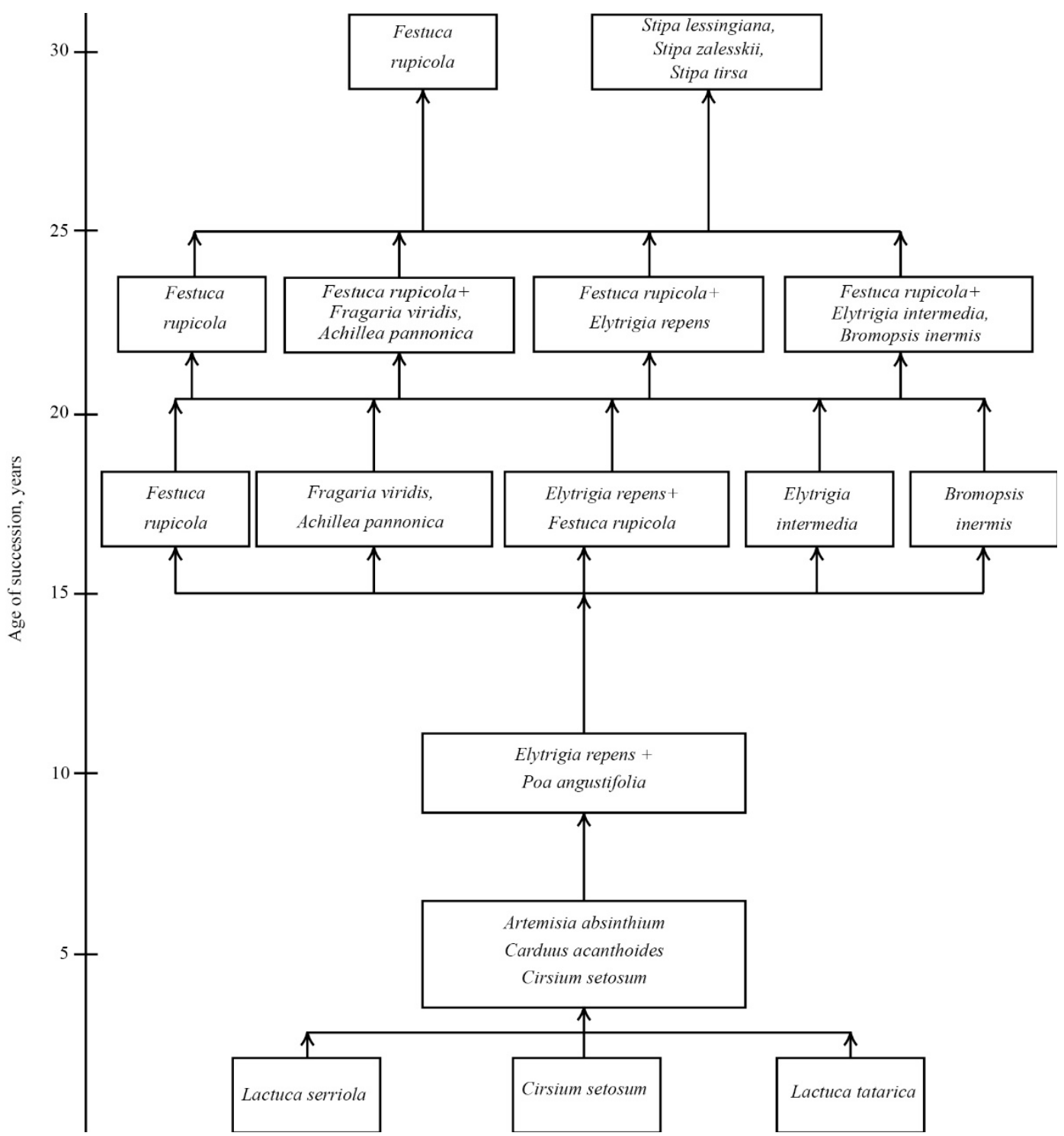

Fig. 1. Succession scheme for abandoned fields in the Starobilski Steppes (Luhansk Oblast, Ukraine) under moderate disturbance, 2005-2017

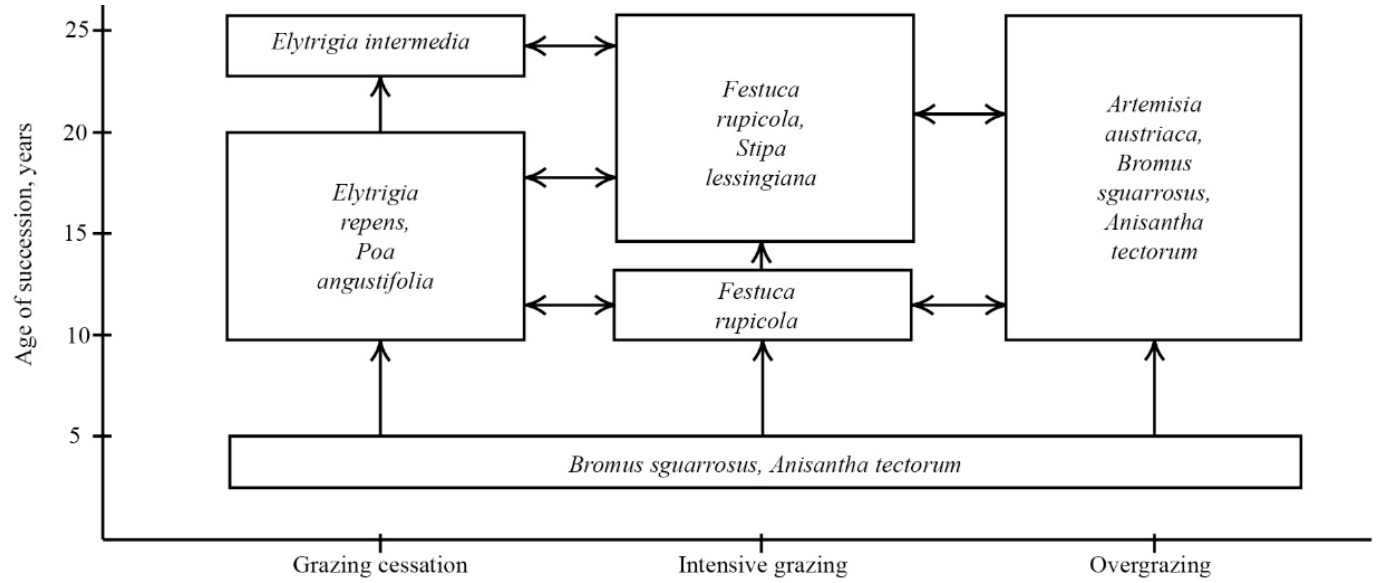

Fig. 2. Succession scheme in abandoned fields in the conditions of heavy grazing in the Starobilski Steppes (Luhansk Oblast, Ukraine), 2005-2017

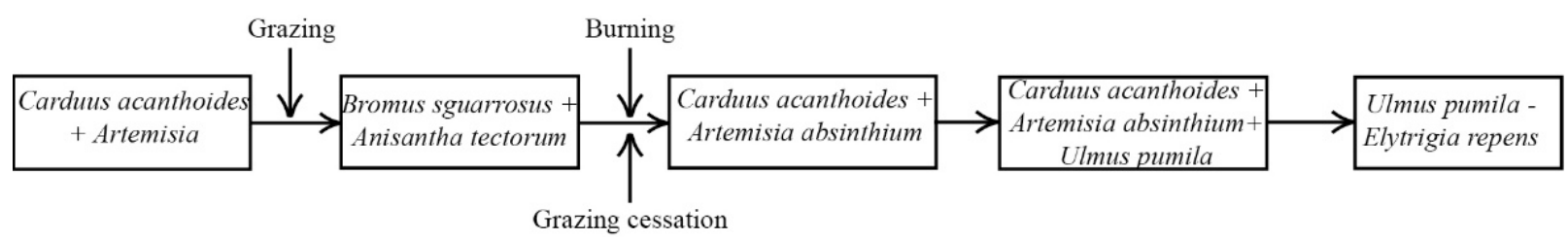

Fig. 3. Scheme of succession in the conditions of short-period grazing in the Starobilski Steppes (Luhansk Oblast, Ukraine), 2005-2017 


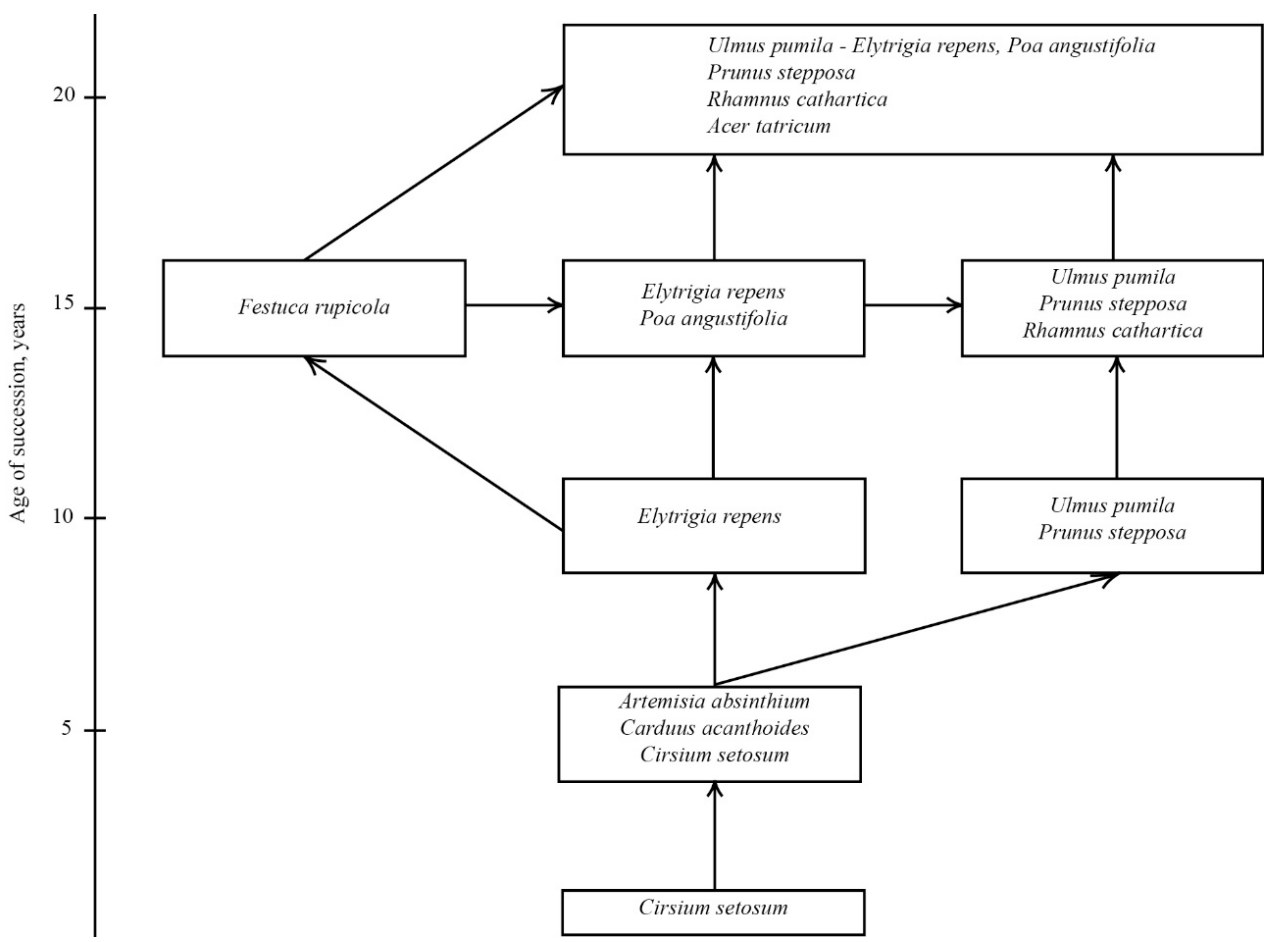

Fig. 4. Scheme of succession of absence of impact in the Starobilski Steppes (Luhansk Oblast, Ukraine), 2005-2017

In the plots with moderate and very moderate impact (most stationary plots), the transition to the bunchgrass stage occurred at the age of 25 years. Secondary bunchgrass communities were characterized by presence of species of early stages - Cirsium setosum, Cichorium intybus, Euphorbia virgata, Carduus acanthoides, Senecio grandidentatus, Poterium polygamum, Picris hieracioides, Daucus carota, Melilotus officinalis, Consolida regalis. At the same time, typical species of steppe communities, which restore slowly in abandoned plots (Bromopsis riparia (Rehmann) Holub, Salvia nutans L., Euphorbia stepposa Zoz., Galatella villosa Rchb. f.), were absent or present in small amount. In such communities, ephemeroid plants was practically absent (sometimes singular specimens were found).

Impact of grazing on the successive processes depends on the intensity of grazing load (Osychnyuk, 1973). The literature data reports both positive influence of grazing on abandoned fields, leading to quite fast formation of steppe communities (Brynkert et al., 2012; Konaikova, 2019), and delay in the process of restoration of vegetation in the conditions of intense grazing (Maksimova, 1957). According to the observations on stationary plots, the fastest restoration of steppe communities and restoration of populations of steppe species took place in the periods of prolonged (several years) cessation of grazing after the period (also accounting for several years) of heavy grazing. In plots disturbed by intense grazing (part of slopes in the Reserve which were intensely used for grazing), over 10 15 years of succession, formation of communities with dominance of Festuca valesiaca and fragments of Stipa communities (mostly with Stipa lessingiana Trin. \&Rupr.) occurred.

In the humid periods (2005-2008), communities of mesotic series were recorded. In the Reserve's steppe biotopes, communities with dominance of Fragaria viridis, Calamagrostis epigeios and even Festuca pratensis Huds formed. Large share of the communities formed in the humid years were found to be stable (thickets of tree-shrub species, fragments with Calamagrostis epigeios, Fragaria viridis). Over the periods of extremely dry seasons, all stationary plots were observed to undergo reduction of the area of mesophytic communities, as well as formation of forb communities with dominance of Achillea pannonica, Artemisia austriaca.

Early stages of succession are quite similar on the different type of soils. Specific species that are confined to certain peculiarities of soils thrive in late stages, and most ruderant plants have broad ecological amplitude. In loamy and carbonate soils, in the weedy stage, there emerged communities with absolute dominance of Carduus acanthoides, with small inclusion of Artemisia absinthium. During the rhizome-grass stage, Elytri- gia repens dominated. In young abandoned fields (7 years), the slopes with carbonate soils, communities with dominance of erosiophile Salvia verticillata $\mathrm{L}$. were described, though such observations were made in the period after intensely humid seasons and could not be considered typical.

In the sites with saline soils and solonetz outcrops in different stages, there were seen communities consisting almost purely of Lactuca tatarica. Later, forb communities of Galatella dracunculoides (Lam.) Ness, Artemisia austriaca, Bassia sedoides (Pall.) Asch. formed. An area of successive age of around 10 years with dominance of Galatella dracunculoides and fragments with Artemisia absinthium, Festuca rupicola were recorded.

Regarding the sabulous soils and outcrops of sands, differences in the succession were more significant because psammophyte ruderant plants are of great diversity. In the young abandoned fields, communities with dominance of Artemisia absinthium and inclusion or dominance of annual ruderant plants (Artemisia scoparia Waldst. \& Kit., Eragrostis minor Host.) were recorded. The stage of rhizome grasses in sabulous soils was expressed poorly or completely absent; communities of cultivated grass Bromopsis inermis were unstable. On the middle-age sites Pilosella officinarum F. Schult. \& Sch. Bip. was dominated. on sandy soils, there was seen fast (10-15 years) formation of communities with dominance of Festuca valesiaca and fragments of Stipa borysthenica Klokov ex Prokudin.

Restoration of native communities is hindered by invasion of alien species, which can entirely change the model and orientation of secondary succession (Fike \& Niering, 1999; Meiners et al., 2001; Meiners et al., 2002; Kuebbing et al., 2014). The most threatening tendency for the Striltsivsky steppe is progressing distribution of tree species spreading from the woody plantations on the Reserve and its surroundings (forest windbreaks, trees in the territory of the manor house in the Reserve). In total, 11 alien tree species growing in the abandoned fields were found, four of which are transformer species that form local thickets in the area of the Reserve and its buffer zone-Acer negundo, Fraxinus lanceolata, Ulmus pumila, Elaeagnus angustifolia L. (Borovyk, 2019). The phytoinvasions have significantly enlarged the diversity of species, which form tree-shrub thickets in the conditions of absence of grazing or mowing. Alien tree species thrive faster than the native ones.

\section{Conclusion}

The peculiarity of succession in abandoned fields in the Starobilski steppes is the formation of communities of a very broad ecological spectrum, typical for abandoned fields both in northern forest steppe regions 
(Bromopsis inermis, Calamagrostis epigeios, Poa angustifolia, Fragaria viridis) and southern ones (Bromus sguarrosus, Anisantha tectorum, Achillea pannonica, Artemisia austriaca), which form depending on the climatic conditions and the type of land use in the period of de-mutation of particular sites. Such peculiarities of abandoned fields in general correspond to the peculiarities of the Starobilski steppes located in the north of Steppe Zone and which combine the features of north meadow steppes and true steppes.

Despite the deepening of anthropogenic transformation of vegetation, restoration of steppe communities can be seen, the subsequence of the stages in general corresponding to the earlier determined scheme classic for steppes. Typical course of succession with restoration of steppe communities was seen only in the areas used for grazing (with moderate disturbance) or where mowing is carried out, providing removal of excessive phytomass and formation of open grass stands, and preventing litter accumulation and distribution of tree species.

The peculiarity of succession in modern conditions is significant duration of all the stages and presence of transitional periods between the stages. In general, late transition to bunchgrass-grass stage (around 25 years) was observed. At the same time, in the conditions of moderate and strong impact of grazing, we saw fast formation of bunch-grass communities (up to 15 years).

A peculiarity of contemporary processes related to the deepening of anthropogenic transformation of vegetation is the formation of shrub thickets during the early stages of succession as a result of distribution of alien tree species (Ulmus pumila, Fraxinus lanceolata, Acer negundo, Elaeagnus angustifolia).

Secondary bunchgrass-grass communities formed in abandoned fields were characterized by significant participation of species of early stages. At the same time, we found that a group species of typical for steppe communities restore in abandoned fields slowly (Bromopsis riparia, Salvia nutans, Euphorbia stepposa, Galatella villosa).

Ecological management of the Reserve must include measures for stimulation of restoration of steppe communities on abandoned sites and opposition to distribution of alien species. As an optimum variant, we should recognize the combination of grazing and mowing (or grazing and periodic fires), that is a method that imitates the natural development of steppe in pre-historic period.

The author would like to thank Doctor of Biological Sciences D. V. Dubina and Candidate of Biological Sciences I. A. Korotchenko for their time with the manuscript, and valuable comments and recommendations.

\section{References}

Albert, A., Mudrak, O., Jongepierova, I., Fajmon, K., Frei, I., Sevcikova, M., Klimesova, J., \& Dolezal, J. (2019). Grassland restoration on ex-arable land by transfer of brush-harvested propagules and green hay. Agriculture, Ecosystems and Environment, 272(15), 7482.

Aleksandrova, V. D. (1964). Izuchenie smen rastitelnogo pokrova [Study of changes in vegetation cover]. In: Lavrenko, E. M., \& Khorchagin, A. A. (Eds.). Polevaya geobotanika [Field Geobotany]. Moscow-Leningrad, Nauka. Vol. 3. Pp. 300 447 (in Russian).

Barbarych, A. I. (Ed.). (1977). Geobotanichne rajonuvannja Ukrajins'koji RSR [Geobotanical Zonation of the Ukrainian SSR]. Naukova Dumka, Kyiv (in Ukrainian).

Bilyk, G. I. (1973). Riznotravno-typchakovo-kovylovi stepy [Herb bunchgrass steppe]. In: Barbarych, A. I. (Ed.). Roslynnist' URSR. Stepy, kam'jani vidslonennja, pisky [Vegetation of the USSR. Steppes, stone outcrops, sands]. Naukova Dumka, Kyiv. Pp. 94-170 (in Ukrainian).

Borovyk, L. (2019). Rol' chuzhoridnyh vydiv u sukcesijah na perelogah u Starobil's'kyh stepah [The role of alien species in abandoned field successions in the Starobilski steppes]. Geo and Bio, 17, 26-38 (in Ukrainian).

Brinkert, A., Kamp, Y., Kheltsel, N., \& Sidorova, T. (2012). Vosstanovleniye rastitel'nosti na zalezhakh v sukhostepnoy podzone Kazakhstana: Vazhnost vypasa [Restoration of vegetation on old-fields in the dry steppe subzone of Kazakhstan: The importance of grazing]. Stepnoy Byulleten, 36, 13-15 (in Russian).

Chusova, O. O. (2018). Biotopy basejnu richky Krasna (Lugans'ka obl., Ukrajina) ta jihnij analiz [Biotopes of the Krasna River basin (Luhansk Region, Ukraine) and their analysis]. Ukrainian Botanical Journal, 75(3), 260-273 (in Ukrainian).
Clark, A. T., Knops, J. M. H., \& Tilman, D. (2019). Contingent factors explain average divergence in functional composition over 88 years of old field succession. Jomal of Ecology, 107(2), 545-558.

Cramer, V. A., \& Hobbs, R. J. (Eds.). (2007). Old fields: Dynamics and restoration of abandoned farmland. Island Press, Washington.

Cramer, V., Hobbs, R., \& Standish, R. (2008). What's new about old fields? Land abandonment and ecosystem assembly. Trends in Ecology and Evolution, 23, $104-112$.

Csecserits, A., \& Redei, T. (2001). Secondary succession on sandy old-fields in Hungary. Applied Vegetation Science, 4(1), 63-74.

Denglera, J., Janisova, M., Török, P., \& Wellstein, C. (2014). Biodiversity of Palaearctic grasslands: A synthesis. Agriculture, Ecosystems and Environment, $182,1-14$.

Didukh, Y. P. (Ed.). (2020). Biotopy stepovoji zony Ukrajiny [Biotopes of Steppe zone of Ukraine]. DrukArt, Kyiv - Chernivtsi.

Didukh, Y. P., \& Scheliag-Sosonko, Y. R. (2003). Geobotanichne raionuvannia Ukrajiny ta sumizhnykh terytorij [Geobotanical zoning of Ukraine and adjacent territories]. Ukrainian Botanical Journal, 60(1), 6-17 (in Ukrainian).

Dowhowera, S. L., Teaguea, W. R., Steigmanb, K., \& Freiheit, R. (2020). Texas Blackland Prairie restoration on old-field vegetation using seeding, mowing, and burning. Arid Land Research and Management, 2020, in press.

Fike, J., \& Niering, W. A. (1999). Four decades of old field vegetation development and the role of Celastrus orbiculatus in the Northeastern United States. Journal of Vegetation Science, 10(4), 483-492.

Fisunenko, O. P., \& Zhadan, V. I. (1994). Priroda Luganskoy oblasti [Nature of the Lugansk region]. Lugansij Gosudarstvennyj Pedagogicheskij Universitet, Lugansk (in Russian).

Knapp, S., Stadler, J., Harpke, A., \& Stefan, K. (2016). Dispersal traits as indicators of vegetation dynamics in long-term old-field succession. Ecological Indicators, $65,44-54$.

Konaikova, V. O. (2019). Ugrupovannja klasu Festuco-Brometea pryrodnogo zapovidnyka "Jelanec'kyj step" [Communities of the class Festuco-Brometea in Yelanetskyi Step Nature Reserve]. Ukrainian Botanical Journal, 76(6), 511-525 (in Ukrainian).

Kuebbing, S. E., Souza, L., Sanders, N. J. (2014). Effects of co-occurring non-native invasive plant species on old-field succession. Forest Ecology and Management, 324(15), 196-204.

Lavrenko, E. M. (1940). Stepi SSSR [Steppes of the USSR]. In: Shishkin, B. K. (Ed.). Rastitel'nost' SSSR [Vegetation of the USSR]. Akademija Nauk SSSR, Moscow-Leningrad. Vol. 2 (in Russian).

Lavrenko, Y. M., Karamyscheva, Z. V., \& Nikulina R. I. (1991). Stepi Evrazii [Steppes of Eurasia]. Nauka, Leningrad (in Russian).

Lysogor, L. P., Bagrikova, N. O., \& Krasova, O. O. (2016). Perelogovi zemli jak perspektyvni vidnovljuval'ni elementy ekomerezhi Pravoberezhnogo stepovogo Prydniprov'ja [Abandoned lands as promising recovery elements of econetwork of the Right-Bank Steppe Dnipro area]. Ukrainian Botanical Journal, 73(2), 116-125 (in Ukrainian).

Maksimova, V. F. (1957). Dinamika rastitelnogo pokrova v svyazi s khozyaystvennoy deyatelnostyu cheloveka [The dynamics of the vegetation cover in connection with human economic activities]. In: Voronov A. G. (Ed.). Trudy Prikaspiyskoy ekspeditsii. Rastitelnost' i kormovyye resursy zapadnoy chasti Prikaspiyskoy nizmennosti i Ergeney [Proceedings of the Caspian expedition. Vegetation and forage resources of the western part of the Caspian lowland and Ergeni]. Moscoskovskij Gosudarstvennyj Universitet, Moscow. Pp. 97-115 (in Russian).

Meiners, S. J., Pickett, S. T. A., \& Cadenasso, M. L. (2002). Exotic plant invasions over 40 years of old-field successions: Community patterns and associations. Ecography, 25, 215-223.

Meiners, S. J., Pickett, S. T. A., \& Cadenasso, M. L. (2001). Effects of plant invasions on the species richness of abandoned agricultural land. Ecography, 24, 633-644.

Mirkin, B. M., \& Naumova, L. G. (2012). Sovremennoe sostojanie osnovnyh koncepcij nauki o rastitel'nosti [The current state of the basic concepts of vegetation science]. Gilem, Ufa (in Russian).

Mosyakin, S. L., \& Fedoronchuk, M. M. (1999). Vascular plants of Ukraine. A nomenclatural checklist. M. G. Kholodny Institute of Botany, Kiev.

Oliinyk, M. P., \& Parpan, V. I. (2017). Vtorynna sukcesija roslynnosti na perelogah Prydnistrovs'kogo Podillja [Secondary succession of vegetation on abandoned lands of Transdnister Podillya]. Ukrainian Botanical Journal, 74(3), 276-283 (in Ukrainian).

Osbornova, J., Kovarova, M., Leps, J., Prach, K. (Eds.). (1990). Succession in abandoned fields Studies in Central Bohemia, Czechslovakia. Kluwer Academic publishers, Dordrecht.

Osychniuk, V. V. (1973). Zminy roslynnogo pokryvu stepu [Changes in the vegetation of the steppe]. In: Barbarych, A. I. (Ed.). Roslynnist' URSR. Stepy, kam'jani vidslonennja, pisky [Vegetation of the USSR. Steppes, stone outcrops, sands]. Naukova Dumka, Kyiv. Pp. 249-333 (in Ukrainian).

Pickett, S. T. A. (1989). Space-for-time substitution as an alternative to long-term studies. In: Likens, G. A. (Ed.). Long-term studies in ecology. Approaches and alternatives. Springer-Verlag, New York. Pp. 110-135. 
Randall, W. M., \& Pickett, S. T. A. (1990). Initial conditions, history and successional pathways in ten contrasting old fields. The American Midland Naturalist, 124(2), 231-238.

Reichhardt, K. L. (1982). Succession of abandoned fields on the shortgass prairie, Northeastern Colorado. The Southwestern Naturalist, 27(3), 299-304.

Rudenko, L. G. (Ed.). (2007). Natsionalnyi atlas Ukrainy [National atlas of Ukraine]. Cartography, Kyiv (in Ukrainian).

Ruprecht, E. (2006). Successfully recovered grassland: A promising example from Romanian old-fields. Restoration Ecology, 14(3), 473- 480.

Ruprecht, E., Enyedi, M. Z., Szabo, A., \& Fenesi, A. (2015). Biomass removal by clipping and raking vs burning for the restoration of abandoned Stipa-dominated European steppe-like grassland. Applied Vegetation Science, 19(1), $78-88$

Sojneková, M., \& Chytrý, M. (2015). From arable land to species-rich semi-natural grasslands: Succession in abandoned fields in a dry region of central Europe. Ecological Engineering, 77, 373-381.

Suyundukov, Y. T., Khasanova, R. F., Salmanova, E. F., Abdullin, M. R., \& Mirkin, B. M. (2008). Fitomeliorativnyy effekt mnogoletnikh trav [Phytomeliorative effect of perennial grasses]. In: Mirkin, B. M., \& Suyundukov, Y. T. (Eds.). Sinantropnaya rastitelnost Zauralia i gorno-lesnoy zony Respubliki Bashkortos- tan: Fitorekultivatsionnyy effect, sintaksonomiya, dinamika [Synanthropic vegetation of the Trans-Urals and the mountain-forest zone of the Republic of Bashkortostan: Phyto-reclamation effect, syntaxonomy, dynamics]. Gilem, Ufa. 26-60 (in Russian)

Tkachenko, V. S. (2009). "Stril'civs'kyj step" v fitocenotychnomu monitoryngu Starobil's'kyh stepiv ["Striltsivskyi step" in phytocoenotic monitoring of Starobilsk steppes]. News Biosphere Reserve "Askania Nova", 11, 6-18 (in Ukrainian).

Török, P., Deak, B., Vida, E., Valkó, O., Lengyel, S., \& Tóthmérész, B. (2010). Restoring grassland biodiversity: Sowing low-diversity seed mixtures can lead to rapid favourable changes. Biological Conservation, 143, 806-812.

Van der Putten, W. H., Mortimer, S. R., Hedlund, K., Van, Dijk, C., Brown, V. K. Lepš, J., Rodriguez-Barrueco, C., Roy, J., Diaz , L. T. A., Gormsen, D., Korthals, G. W., Lavorel, S., Santa Regina, I., \& Smilauer, P. (2000). Plant species diversity as a driver of early succession in abandoned fields: A multi-site approach. Oecologia, 124, 91-99.

Vlasov, Y. M. (Ed.). (2011). Ahroklimatychnyi dovidnyk po Luhanskii oblasti (1986-2005) [Agro-climate handbook for Luhansk Oblast (1986-2005)]. Virtualna Real'nist', Luhansk (in Ukrainian). 